\title{
PENGARUH PENGEMBANGAN KARIR, PENEMPATAN KERJA, TINGKAT PENDIDIKAN, TEKNOLOGI INFORMASI DAN FASILITAS KERJA TERHADAP KINERJA KARYAWAN \\ (Studi Kasus pada Kantor Badan Kependudukan dan Keluarga Berencana Nasional Provinsi Jawa Tengah)
}

\section{Soegihartono}

Diterima: Agustus 2019, Disetujui: September 2019, Dipublikasikan: Oktober 2019

\begin{abstract}
This study aims to empirically examine and analyze the effect of career development, work placement, education level, information technology, and work facilities on employee performance at the office of population and family planning in central java.

The sample in this study was determined as many as 100 employees at the Central Java National Population and Family Planning Office that were taken using random sampling techniques. The data obtained in this study were processed using multiple regression analysis techniques with validity and reliability tests supported by SPSS version 23 software.

Based on the results of the analysis and discussion in this study the regression results obtained $Y=-2,386+0,148 X 1+0,299 X 2+0,587 X 3+0,249 X 4+0,941 X 5$. Based on the results of the hypothesis it can be stated that the variables in this study, namely career development (X1), work placement (X2), education level (X3), information technology (X4), and work facilities (X5) have a positive and significant effect on employee performance .

Keywords: Career Development, Job Placement, Education Level, Information Technology, Work Facilities, and Employee Performance.
\end{abstract}

Abstrak
Penelitian ini bertujuan untuk menguji secara empiris dan menganalisis pengaruh pengembangan karir, penempatan kerja, tingkat pendidikan, teknologi informasi, dan fasilitas kerja terhadap kinerja karyawan pada Kantor Badan Kependudukan dan Keluarga Berencana Nasional Jawa Tengah.

Sampel dalam penelitian ini ditentukan sebanyak 100 pegawai pada Kantor Badan Kependudukan dan Keluarga Berencana Nasional Jawa Tengah yang diambil dengan menggunakan teknik random sampling. Data yang diperoleh dalam penelitian ini diolah menggunakan teknik analisis regresi berganda dengan uji validitas dan reliabilitas dengan didukung software SPSS versi 23.

Berdasarkan hasil analisis dan pembahasan pada penelitian ini diperoleh hasil regresi $Y=-2,386+0,148 X_{1}+0,299 X_{2}+0,587 X_{3}+0,249 X_{4}+0,941 X_{5}$. Berdasarkan hasil hipotesis maka dapat dinyatakan bahwa variabel dalam penelitian ini, yaitu pengembangan karir $\left(X_{1}\right)$, penempatan $\operatorname{kerja}\left(X_{2}\right)$, tingkat pendidikan $\left(X_{3}\right)$, teknologi informasi $\left(\mathrm{X}_{4}\right)$, dan fasilitas kerja $\left(\mathrm{X}_{5}\right)$ berpengaruh positif dan signifikan terhadap kinerja karyawan.

Kata kunci : Pengembangan Karir, Penempatan Kerja, Tingkat Pendidikan, Teknologi Informasi, Fasilitas Kerja, dan Kinerja Karyawan. 


\section{PENDAHULUAN}

Sebagai salah satu instansi pemerintah yang bergerak dibidang pelayanan masyarakat dalam kaitannya menangani kependudukan dan keluarga berencana, maka Badan Kependudukan dan Keluarga Berencana Nasional Provinsi Jawa Tengah harus melakukan pekerjaannya dengan cepat dan tepat. Tercapainya tujuan dari Badan Kependudukan dan Keluarga Berencana Nasional Provinsi Jawa Tengah tidak lepas dari kinerja pegawai didalamnya. Namun demikian penulis melihat bahwa ada indikator penurunan kinerja yang ditinjau dari hasil rekap absensi selama tiga bulan yang ditampilkan dalam tabel berikut :

\section{Tabel 1}

\section{Absensi Pegawai Bulan Januari - Maret 2018}

\begin{tabular}{|c|c|c|c|c|c|c|c|c|c|}
\hline \multirow[b]{2}{*}{ BULAN } & \multirow[b]{2}{*}{$\begin{array}{l}\text { JUMLAH } \\
\text { PEGAWAI }\end{array}$} & \multicolumn{8}{|c|}{ ALASAN ABSEN } \\
\hline & & SAKIT & $\%$ & IZIN & $\%$ & $\begin{array}{l}\text { TANPA } \\
\text { KETERANGAN }\end{array}$ & $\%$ & JUMLAH & $\%$ \\
\hline Januari & 194 & 5 & 2,5 & 7 & 3,6 & 11 & 5,6 & 23 & 11,8 \\
\hline Februari & 194 & 2 & 1 & 5 & 2,5 & 9 & 4,6 & 16 & 8,2 \\
\hline Maret & 194 & 4 & 2 & 3 & 1,5 & 14 & 7,2 & 21 & 10,8 \\
\hline
\end{tabular}

Sumber : BKKBN Provinsi Jawa Tengah

Berdasarkan data pada tabel 1 diatas maka dapat disimpulkan bahwa telah terjadi penurunan kehadiran pegawai yang terlihat pada kenaikan jumlah absensi selama tiga bulan terakhir (Januari hingga Maret 2018). Pada bulan Januari terhitung jumalah presentase ketidakhadiran pegawai sebesar 11,8\% yang kemudian turun sebesar 3,6\% menjadi $8,2 \%$ pada bulan Februari. Kemudian juga pada bulan Maret terjadi peningkatan jumlah ketidakhadiran pegawai sebesar 2,6\% menjadi 10,8\%. Melihat adanya penurunan dan peningkatan jumlah pegawai yang absen selama tiga bulan terakhir, maka hal ini berdampak pada kinerja pegawai. Karena ketika pegawai tidak datang bekerja, maka pegawai tersebut tidak dapat melakukan tugas-tugas yang seharusnya mereka kerjakan. Selain dengan mencatat kehadiran pegawai atau absensi penilaian kinerja pegawai di Badan Kependudukan dan Keluarga Berencana Nasional Provinsi Jawa Tengah dilaksanakan dengan melakukan pengawasan dan inspeksi mendadak pada jam kerja serta melarang pegawai keluar kantor pada jam kerja dan bagi yang melaksanakan tugas dinas ke luar kota harus membawa surat tugas. Dengan demikian maka para pegawai tidak dapat sewenang-wenang dalam menjalankan pekerjaan yang dibebankan oleh Pimpinan agar tujuan instansi dapat tercapai. 


\section{Rumusan Masalah}

Berdasarkan permasalahan diatas maka akan diadakan penelitian lebih lanjut, maka rumusan masalah dirumuskan sebagai berikut.

1. Apakah pengembangan karir berpengaruh terhadap kinerja karyawan Badan Kependudukan dan Keluarga Berencana Nasional Provinsi Jawa Tengah?

2. Apakah penempatan kerja berpengaruh terhadap kinerja karyawan Badan Kependudukan dan Keluarga Berencana Nasional Provinsi Jawa Tengah?

3. Apakah tingkat pendidikan karyawan berpengaruh terhadap kinerja karyawan Badan Kependudukan dan Keluarga Berencana Nasional Provinsi Jawa Tengah?

4. Apakah teknologi informasi berpengaruh terhadap kinerja karyawan Badan Kependudukan dan Keluarga Berencana Nasional Provinsi Jawa Tengah?

5. Apakah fasilitas kerja terhadap kinerja karyawan Badan Kependudukan dan Keluarga Berencana Nasional Provinsi Jawa Tengah?

\section{Tujuan Penelitian}

Adapun tujuan dari pada penelitian ini adalah untuk memperoleh gambaran yang mendalam dan memberikan bukti empiris mengenai pengaruh pengembangan karir , penempatan kerja , tingkat pendidikan, dan fasilitas kerja terhadap kinerja karyawan. Berdasarkan latar belakang dan rumusan masalah yang ada maka penelitian ini dilakuakan dengan tujuan :

1. Menganalisis dan menguji pengaruh pengembangan karir terhadap kinerja karyawan Badan Kependudukan dan Keluarga Berencana Nasional Provinsi Jawa Tengah.

2. Menganalisis dan menguji penempatan kerja terhadap kinerja karyawan Badan Kependudukan dan Keluarga Berencana Nasional Provinsi Jawa Tengah.

3. Menganalisis dan menguji pengaruh tingkat pendidikan terhadap kinerja Badan Kependudukan dan Keluarga Berencana Nasional Provinsi Jawa Tengah.

4. Menganalisis dan menguji pengaruh Teknologi Informasi terhadap kinerja Badan Kependudukan dan Keluarga Berencana Nasional Provinsi Jawa Tengah.

5. Menganalisis dan menguji pengaruh Fasilitas Kerja terhadap kinerja Karyawan Badan Kependudukan dan Keluarga Berencana Nasional Provinsi Jawa Tengah. 


\section{LANDASAN TEORI}

\section{Kinerja}

Menurut Komaruddin (2002 : 16) menyatakan “ kinerja adalah suatu keadaan yang menunjukkan tingkat keberhasilan kegiatan manajemen dalam mencapai tujuan manajer, artinya manajemen yang efektif tidak selalu harus disertai efisiensi yang maksimum". Dengan demikian kinerja dapat dilihat sebagi suatu kemampuan untuk memilih tujuan yang tepat. Dalam mencapai suatu tujuan tertentu atau efektivitas kerja dapat juga diartikan dengan hasil guna penekananya pada efeknya, atau hasil tanpa kurang memperdulikan pengorbanan yang perlu diberikan oleh hasil tersebut. Kinerja dalam organisasi merupakan usaha untuk mencapai prestasi yang maksimal dengan menggunakan sumber daya yang tersedia dalam waktu yang relatif singkat tanpa menunggu keseimbangan tujuan alat dan tenaga serta waktu.

\section{Pengembangan Karir}

Martoyo (2007:74) mengemukakan bahwa pengembangan karir adalah suatu kondisi yang menunjukkan adanya peningkatan-peningkatan status seseorang dalam suatu organisasi dalam jalur karir yang telah ditetapkan dalam organisasi yang bersangkutan. Handoko (2012:130-131) mengemukakan bahwa pengembangan karir merupakan upaya-upaya pribadi seoarang pegawai untuk mencapai suatu rencana karir.

Andrew J. Dubrin (1982) mengemukakan bahwa pengembangan karir adalah aktivitas kepegawaian yang membantu pegawai-pegawai merencanakan karier masa depan mereka di perusahaan agar perusahaan dan pegawai yang bersangkutan dapat mengembangkan diri secara maksimum. Definisi yang semakna juga bahwa pengembangan karir adalah suatu langkah yang ditempuh perusahaan untuk menghadapi tuntutan tugas karyawan dan untuk menjawab tantangan masa depan dalam mengembangkan sumber daya manusia di perusahaan yang merupakan suatu keharusan dan mutlak diperlukan (Siagian, 2001).

\section{Penempatan Kerja}

Sastrohadiwiryo (2002:162) mengemukakan bahwa penempatan kerja adalah proses pemberian tugas dan pekerjaan kepada karyawan yang lulus seleksi untuk dilaksanakan sesuai ruang lingkup yang telah ditetapkan, serta mampu mempertanggungjawabkan segala resiko dan kemungkinan-kemungkinan yang terjadi atas tugas dan pekerjaan, wewenang serta tanggung jawab. Penempatan sebagai suatu 
langkah eksperimental yang sebenarnya bukanlah merupakan sebuah keputusan final. Mathis dan Jackson (2006:262) mengemukakan bahwa penempatan adalah menempatkan posisi seseorang ke posisi pekerjaan yang tepat, seberapa baik seorang karyawan cocok dengan pekerjaanya akan mempengaruhi jumlah dan kualitas pekerjaan.

\section{Tingkat Pendidikan}

Sutrisno (2011:65) menyatakan pendidikan merupakan totalitas interaksi manusia untuk pengembangan manusia seutuhnya, dan pendidikan merupakan proses yang terus-menerus yang senantiasa berkembang. Melalui pendidikan seseorang dipersiapkan untuk memiliki bekal agar siap tahu, mengenal dan mengembangkan metode berfikir secara sistematis agar dapat memecahkan masalah yang akan dihadapi dalam kehidupan dikemudian hari (Sedarmayanti, 2003:32)

\section{Teknologi Informasi}

Teknologi informasi adalah suatu studi perancangan, implementasi, pengembangan, dukungan atau manajemen sistem informasi berbasis komputer, terutama pada aplikasi hardware (perangkat keras) dan software (perangkat lunak) secara sederhana, pengertian teknologi informasi adalah fasilitas-fasilitas yang terdiri dari perangkat keras dan perangkat lunak dalam mendukung dan meningkatkan kualitas informasi untuk setiap lapisan masyarakat secara cepat dan berkualitas. Pengertian teknologi informasi menurut Martin (1999) dalam Rakhmansyah dan Susilo (2014), adalah bahwa teknologi informasi tidak hanya terbatas pada teknologi komputer (perangkat keras dan perangkat lunak) yang digunakan untuk memproses dan menyimpan informasi, melainkan juga mencakup komunikasi untuk mengirimkan informasi.

\section{Fasilitas Kerja}

Fasilitas adalah sarana untuk melancarkan dan memudahkan pelaksanaan fungsi. Fasilitas merupakan komponen individual dari penawaran yang mudah ditumbuhkan atau dikurangi tanpa mengubah kualitas dan model jasa. Fasilitas juga merupakan alat untuk membedakan program lembaga pendidikan yang satu dari pesaing yang lainnya (Lupiyaodi, 2006 : 150 ). Fasilitas kerja adalah sarana pendukung dalam aktivitas perusahaan berbentuk fisik, dan digunakan dalam kegiatan normal perusahaan, memiliki jangka waktu kegunaan yang relatif permanen dan memberikan manfaat untuk masa 
yang akan dating. Fasilitas kerja sangatlah penting bagi perusahaan, karena dapat menunjang kinerja karyawan, seperti dalam penyelesaian pekerjaan.

Berdasarkan definisi Fasilitas diatas, maka dapat disimpulkan bahwa failitas adalah salah satu sarana pendukung untuk menciptakan motivasi kerja terhadap kinerja pegawai.Menurut Nitisemito (2001 : 65) mengemukakan fasilitas adalah rasa menyenangkan yang diberikan kepada orang lain disertai kemudahan untuk memenuhi kebutuhan mereka.

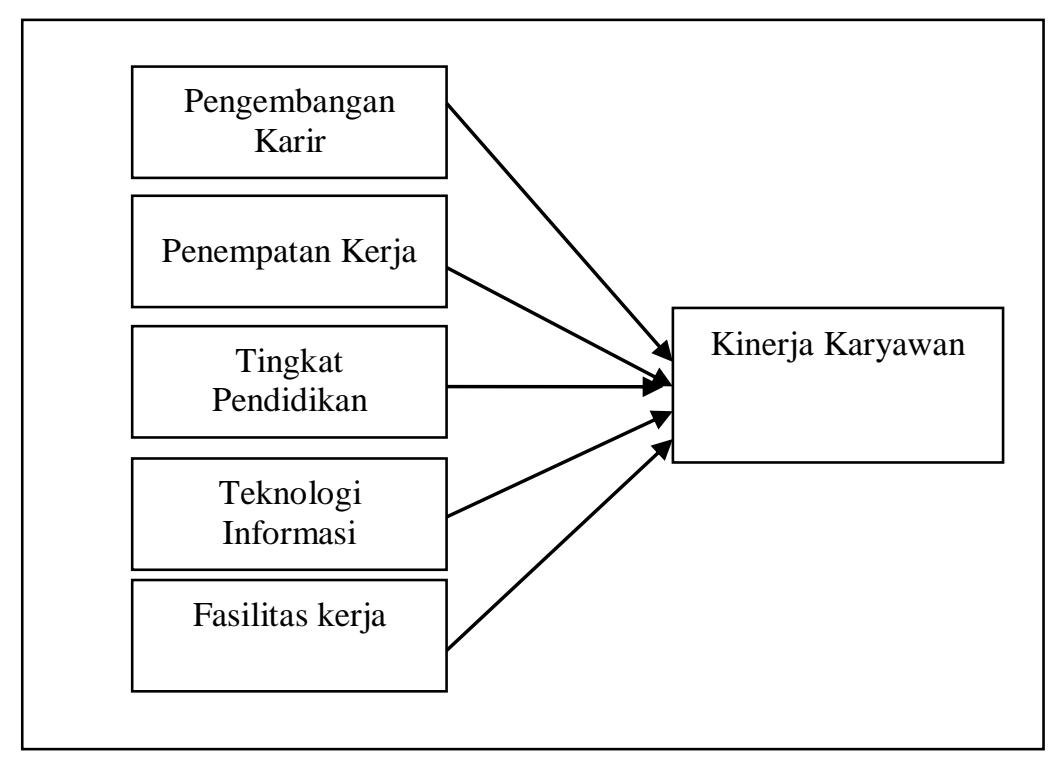

Gambar 1

\section{Kerangka Pikir Teoritis}

Menurut Sugiyono (2013:2) mendefinisikan metode penelitian adalah "Metode Penelitian pada dasarnya merupakan cara ilmiah untuk mendapatkan data yang valid dengan tujuan yang bersifat penemuan, pembuktian dan pengembangan suatu pengetahuan sehingga hasilnya dapat digunakan untuk memahami, memecahkan dan mengantisipasi masalah" Metode yang digunakan dalam penelitian ini adalah metode deskriptif dan metode verifikatif dengan pendekatan kuantitatif. Menurut Kerlinger (2006) hipotesis merupakan pernyataan dugaan (conjectural) tentang hubungan antara dua variabel atau lebih. Hipotesis selalu mengambil bentuk kalimat pernyataan dan 
menghubungkan secara umum maupun khusus antara variabel yang satu dengan variabel yang lainnya.

$\mathrm{H}_{1}$ : Pengembangan karir berpengaruh positif dan signifikan terhadap kinerja karyawan

$\mathrm{H}_{2}$ : Penempatan kerja berpengaruh positif dan signifikan terhadap kinerja karywan.

$\mathrm{H}_{3}$ : Tingkat Pendidikan berpengaruh dan signifikan terhadap kinerja karyawan.

$\mathrm{H}_{4}$ : Teknologi Informasi berpengaruh positif dan signifikan terhadap kinerja karyawan.

$\mathrm{H}_{5}$ : Fasilitas Kerja berpengaruh positif dan signifikan terhadap kinerja karyawan.

\section{METODE PENELITIAN}

Dalam penelitian ini penulis melakukan penelitian pada Kantor BKKBN Provinsi Jawa Tengah. Populasi dalam penelitian ini adalah seluruh pegawai pada Kantor BKKBN Provinsi Jawa Tengah sebanyak 194 pegawai. Data ini didapatkan berdasarkan data dari Kantor BKKBN Provinsi Jawa Tengah.

Dalam penelitian ini, Karena subjek dari penelitian ini lebih besar dari 100 maka sampel dalam penelitian ini ditentukan sebanyak 50\% dari jumlah populasi. Dengan demikian sampel dalam penelitian ini adalah 50\% x 194 orang $=97$ orang, maka dibulatkan menjadi 100 orang.

Skala yang digunakan dalam penyusunan kuesioner atau angket ini adalah skala interval:

$$
\begin{aligned}
& 1 \text { = Sangat Tidak Setuju } \\
& 2=\text { Tidak Setuju } \\
& 3=\text { Netral } \\
& 4=\text { Setuju } \\
& 5=\text { Sangat Setuju }
\end{aligned}
$$

Skala LIKERT dikatakan ordinal bila pernyataan Sangat Setuju mempunyai tingkat atau preferensi yang "lebih tinggi" dari Setuju, dan "lebih tinggi" dari "Netral" (Ghozali, 2013:146).

Dalam penelitian ini metode yang digunakan untuk penelitian yakni menggunakan Analisis Regresi linier berganda sebagai alat analisis untuk mengetahui pengaruh variabel bebas yaitu pengembangan karir, penempatan kerja, tingkat 
pendidikan, teknologi informasi, dan fasilitas kerja terhadap variabel terikat kinerja karyawan . Bentuk regresi linier berganda adalah sebagai berikut :

$$
Y=\beta 0+\beta 1 . X 1+\beta 2 . X 2+\beta 3 . X 3+\beta 4 . X 4+\beta 5 . X 5 .
$$

Dimana :

$$
\begin{array}{ll}
\mathrm{Y} & =\text { Variabel terikat (kinerja karyawan) } \\
\mathrm{X} 1 & =\text { Variabel bebas (pengembangan karir) } \\
\mathrm{X} 2 & =\text { Variabel bebas (penempatan kerja) } \\
\mathrm{X} 3 & =\text { Variabel bebas ( tingkat pendidikan) } \\
\mathrm{X} 4 & =\text { Variabel bebas ( teknologi informasi) } \\
\mathrm{X} 5 & =\text { Variabel bebas (fasilitas kerja) } \\
\beta 0 & =\text { Konstanta } \\
\beta 1, \beta 2, \beta 3, \beta 4, \beta 5 & =\text { Koefisien masing-masing variabel bebas }
\end{array}
$$

\section{HASIL DAN PEMBAHASAN}

\section{Proses Penyebaran dan Penerimaan Kuesioner}

Pengumpulan data pada penelitian ini dilakukan melalui penyebaran kuesioner yang dibagikan secara langsung kepada responden. Penyebaran kuesioner ini dilakukan dengan membagikan kuesioner secara langsung kepada responden. Penyebaran sebanyak 100 kuesioner yang disebar kepada karyawaan Kantor Badan Kependudukan dan Keluarga Berencana Nasional Priovinsi Jawa Tengah yang dapat dilihat dari table 2

Tabel 2

Proses Penyebaran dan Penerimaan Kuesioner

\begin{tabular}{|l|l|l|}
\hline Responden & Jumlah & Persentase \\
\hline Kuesioner yang disebar & 100 & $100 \%$ \\
\hline Kuesioner yang tidak kembali & 0 & $0 \%$ \\
\hline Kuesioner yang dapat diolah & 100 & $100 \%$ \\
\hline
\end{tabular}

Sumber : Data yang diolah, 2018

Tabel diatas menunjukkan bahwa kuesioner yang dibagikan kepada responden sebanyak 100 kuesioner, dengan tingkat pengembalian sebesar 100\% yang berarti bahwa seluruh kuesioner kembali dan dapat diolah . 


\section{Analisis Deskriptif Karakteristik Responden}

Dalam analisis deskriptif yang pertama kali dilakukan dalam penelitian ini adalah analisis terhadap responden. Dalam penelitian ini karakteristik yang ingin diketahui adalah jenis kelamin, usia, pendidikan, lama bekerja, dan bekerja pada bidang masing-masing karyawan. Untuk lebih jelasnya mengenai karakteristik dapat dilihat pada tebel yang telah disajikan dalam bentuk table yang menunjukkan besarnya dalam jumlah presentase.

\section{Karakteristik Responden}

\section{a. Jenis Kelamin Responden}

Jenis kelamin yang disajikan sebagai responden dalam penelitian ini adalah sebagai berikut:

\section{Tabel 3}

Data Responden Berdasarkan Jenis Kelamin

\begin{tabular}{|l|l|l|l|}
\hline No. & Jenis Kelamin & Frekuensi & Persentase \\
\hline 1. & Laki-laki & 44 & $44 \%$ \\
\hline 2. & Perempuan & 56 & $56 \%$ \\
\hline \multicolumn{2}{|l}{ Jumlah } & $\mathbf{1 0 0}$ & $\mathbf{1 0 0 \%}$ \\
\hline
\end{tabular}

Sumber : Data primer yang diolah, 2018

Pada table diatas menunjukkan bahwa responden yang terdapat pada Kantor Badan Kependudukan dan Keluarga Berencana Nasional Provinsi Jawa Tengah lebih banyak berjenis kelamin perempuan bila dibandingkan dengan jenis kelamin laki-laki, yaitu responden perempuan sebanyak 56 responden atau 56\% \% sedangkan yang berjenis laki-laki sebanyak 44 responden atau $44 \%$. Berdasarkan hal tersebut maka dapat disimpulkan bahwa sebagian besar yang menjadi responden adalah di dominasi oleh pegawai perempuan. Sehingga jenis kelamin/ gender tertentu bukan merupakan tolak ukur untuk berkerja di Kantor Badan Kependudukan dan Keluarga Berencana Nasional Provinsi Jawa Tengah . 


\section{b. Umur Responden}

Berdasarkan hasil penelitian, umur responden dikelompokkan sebagai berikut:

\section{Tabel 4}

\section{Data Umur Responden}

\begin{tabular}{|l|l|l|l|}
\hline No. & Umur & Frekuensi & Presentase \\
\hline 1. & $<25$ & 15 & $15 \%$ \\
\hline 2. & $26-40$ & 48 & $48 \%$ \\
\hline 3. & $>40$ & 37 & $37 \%$ \\
\hline Jumlah & $\mathbf{1 0 0}$ & $\mathbf{1 0 0 \%}$ \\
\hline
\end{tabular}

Sember : Data primer yang diolah, 2018

Berdasarkan table 4 diatas menunjukkan bahwa sebanyak 15 responden atau $15 \%$ berumur kurang dari 25 tahun, sedangkan yang berumur antara 26-40 tahun sebanyak 48 responden atau $48 \%$ dan responden yang berumur diatas 40 tahun sebanyak 37 responden atau 37\%. Hal ini menunjukkan bahwa pada umumnya responden masih tergolong produktif sehingga secara kualitas maupun kuantitas dapat memberikan kontribusi bagi Kantor Kantor Badan Kependudukan dan Keluarga Berencana Nasional Provinsi Jawa Tengah untuk mencapai tujuan yang diinginkan.

\section{c. Pendidikan}

Berdasarkan hasil penelitian, pendidikan pegawai aan Kantor Badan Kependudukan dan Keluarga Berencana Nasional Priovinsi Jawa Tengahdikelompokkan dalam kriteria sebagai berikut:

Tabel 5

Data Pendidikan Responden

\begin{tabular}{|l|l|l|l|}
\hline No & Pendidikan & Frekuensi & Presentase \\
\hline 1 & SLTA & 12 & $12 \%$ \\
\hline 2 & D III & 28 & $28 \%$ \\
\hline 3 & S-1 & 46 & $46 \%$ \\
\hline 4 & S-2 & 14 & $14 \%$ \\
\hline Jumlah & $\mathbf{1 0 0}$ & $\mathbf{1 0 0 \%}$ \\
\hline
\end{tabular}

Sumber : Data primer yang diolah, 2018

Berdasarkan table diatas menunjukkan bahawa pegawai Kantor Badan Kependudukan dan Keluarga Berencana Nasional Priovinsi Jawa Tengah yang berpendidikan SLTA sebanyak 12 responden 12\%, sedangkan yang berpendidikan D III sebanyak 28 responden atau 28\%, untuk tingkat pendidikan S-1 terdapat 46 esponden atau $46 \%$ dan tingkat pendidikan S-2 sebanyak 14 responden atau 14\%. 


\section{d. Lama bekerja}

Berdasarkan hasil penelitian, lama bekerja pegawai aan Kantor Badan Kependudukan dan Keluarga Berencana Nasional Priovinsi Jawa Tengah dikelompokkan dalam kriteria sebagai berikut:

\section{Tabel 6}

Data Lama Bekerja Responden

\begin{tabular}{|l|l|l|l|}
\hline No & Lama bekerja & Frekuensi & Presentase \\
\hline 1 & $<5$ tahun & 8 & $8 \%$ \\
\hline 2 & $5-10$ tahun & 13 & $13 \%$ \\
\hline 3 & $10-20$ tahun & 36 & $36 \%$ \\
\hline 4 & $>20$ tahun & 43 & $43 \%$ \\
\hline Jumlah & $\mathbf{1 0 0}$ & $\mathbf{1 0 0 \%}$ \\
\hline
\end{tabular}

Sumber : Data primer yang diolah, 2018

Berdasarkan tabel diatas menunjukkan bahwa pegawai Kantor Badan

Kependudukan dan Keluarga Berencana Nasional Priovinsi Jawa Tengah yang telah bekerja kurang dari 5 tahun sebanyak 8 responden atau $8 \%$ sedangkan yang bekerja selama 5 - 10 tahun sebanyak 13 responden atau $13 \%$ responden yang bekerja kurang lebih 10 - 20 tahun sebanyak 36 atau 36\%, dan responden yang telah lama bekerja lebih dari 20 tahun sebanyak 43 orang dengan persentase $43 \%$.

\section{Uji Validitas dan Reabilitas}

\section{Uji Validitas}

Validitas adalah suatu alat ukur untuk menguji item pernyataan (kuesioner) sehingga suatu penelitian yang menggunakan kuesioner sebagai alat penguukurnya perlu diuji validitasnya. Uji validitas menggunakan nilai $r$ hitung (nilai Correted itemTotal Correlation pada output Cronbach alpha ) pada SPSS versi 23 . Menurut Imam Ghozali (2005), apabila $\mathrm{r}$ hitung > $\mathrm{r}$ tabel, maka dinyatakan valid . Adapun pengujian validitas variabael pengembangan karir, penempatan kerja, tingkat pendidikan, teknologi informasi, dan $\mathrm{f}$ asilitas kerja terhadap kinerja karyawan dapat dilihat pada table 7 berikut ini : 
Tabel 7

Pengujian Validitas Variabel Penelitian

\begin{tabular}{|c|c|c|c|c|}
\hline No & Indikator & $\mathbf{r}$ hitung & $\mathbf{r}$ tabal & Keterangan \\
\hline \multicolumn{5}{|c|}{ Pengembangan Karir } \\
\hline 1 & $\mathrm{X}_{1.1}$ & 0,778 & 0,1966 & Valid \\
\hline 2 & $\mathrm{X}_{1.2}$ & 0,786 & 0,1966 & Valid \\
\hline 3 & $\mathrm{X}_{1.3}$ & 0,788 & 0,1966 & Valid \\
\hline 4 & $\mathrm{X}_{1.4}$ & 0,709 & 0,1966 & Valid \\
\hline 5 & $\mathrm{X}_{1.5}$ & 0,807 & 0,1966 & Valid \\
\hline 6 & $\mathrm{X}_{1.6}$ & 0,782 & 0,1966 & Valid \\
\hline 7 & $\mathrm{X}_{1.7}$ & 0,725 & 0,1966 & Valid \\
\hline \multicolumn{5}{|c|}{ Penempatan Kerja } \\
\hline 1 & $\mathrm{X}_{2.1}$ & 0,798 & 0,1966 & Valid \\
\hline 2 & $\mathrm{X}_{2.2}$ & 0,871 & 0,1966 & Valid \\
\hline 3 & $\mathrm{X}_{2.3}$ & 0,823 & 0,1966 & Valid \\
\hline 4 & $\mathrm{X}_{2.4}$ & 0,790 & 0,1966 & Valid \\
\hline \multicolumn{5}{|c|}{ Tingkat Pendidikan } \\
\hline 1 & $\mathrm{X}_{3.1}$ & 0,803 & 0,1966 & Valid \\
\hline 2 & $\mathrm{X}_{3.2}$ & 0,757 & 0,1966 & Valid \\
\hline 3 & $\mathrm{X}_{3.3}$ & 0,827 & 0,1966 & Valid \\
\hline \multicolumn{5}{|c|}{ Teknologi Informasi } \\
\hline 1 & $\mathrm{X}_{4.1}$ & 0,806 & 0,1966 & Valid \\
\hline 2 & $\mathrm{X}_{4.2}$ & 0,757 & 0,1966 & Valid \\
\hline 3 & $\mathrm{X}_{4.3}$ & 0,804 & 0,1966 & Valid \\
\hline 4 & $\mathrm{X}_{4.4}$ & 0,806 & 0,1966 & Valid \\
\hline 5 & $\mathrm{X}_{4.5}$ & 0,868 & 0,1966 & Valid \\
\hline \multicolumn{5}{|c|}{ Fasilitas Kerja } \\
\hline 1 & $\mathrm{X}_{5.1}$ & 0,790 & 0,1966 & Valid \\
\hline 2 & $\mathrm{X}_{5.2}$ & 0,823 & 0,1966 & Valid \\
\hline 3 & $\mathrm{X}_{5.3}$ & 0,797 & 0,1966 & Valid \\
\hline
\end{tabular}




\begin{tabular}{|l|l|l|l|l|}
\hline 4 & $X_{5.4}$ & 0,751 & 0,1966 & Valid \\
\hline 5 & $X_{5.5}$ & 0,863 & 0,1966 & Valid \\
\hline \multicolumn{4}{|l|}{} \\
\hline 1 & $Y_{1}$ & 0,730 & 0,1966 & Valid \\
\hline 2 & $Y_{2}$ & 0,771 & 0,1966 & Valid \\
\hline 3 & $Y_{.3}$ & 0,860 & 0,1966 & Valid \\
\hline 4 & $Y_{4}$ & 0,686 & 0,1966 & Valid \\
\hline 5 & $Y_{5}$ & 0,818 & 0,1966 & Valid \\
\hline 6 & $Y_{6}$ & 0,801 & 0,1966 & Valid \\
\hline 7 & $Y_{7}$ & 0,745 & 0,1966 & Valid \\
\hline 8 & $Y_{8}$ & 0,840 & 0,1966 & Valid \\
\hline 9 & $Y_{9}$ & 0,829 & 0,1966 & Valid \\
\hline
\end{tabular}

Sumber : Data primer yang diolah, 2018

Berdasarkan pengujian validitas seperti yang terlihat pada table 7 diatas menunjukkan bahwa masing-masing indikator terhadap total skor dari setiap variabel menunjukkan hasil yang signifikan, dan menunjukkan bahwa $r$ hitung $>r$ table $(\mathrm{N}=100$ $=0,1966$ dari $\mathrm{r}$ table 5\% baris 98). Sehingga dapat disimpulkan bahwa semua item pertanyaan kuesioner dinyatakan valid, sehingga dapat dilanjutkan pengujian selanjutnya.

\section{Uji Reliabilitas}

Uji Reliabilitas adalah alat ukur untuk mengukur suatu kuesioner yang merupakan indikator dari variabel atau konstruk. Suatu kuesioner dikatakan reliable atau handal jika jawaban seseorang terhadap peryataan adalah konsisten dan stabil dari waktu ke waktu (Ghozali, 2009). Pengukuran reliabilitas dilakukan dengan One shot, yaitu pengukuran yang dilakukan sekali saja dan hasilnya kemudian dibandingkan dengan pernyataan atau mengukur korelasi antar jawaban peryataan. Suatu konstruk atau variabel dikatakan valid apabila memberikan nilai Cronbach Alpha > 0,60 (Ghozali,2009). 


\section{Tabel 8}

Pengujian Reliabilitas

\begin{tabular}{|l|l|l|l|l|}
\hline No & Variabel & $\begin{array}{l}\text { Nilai } \\
\text { Cronbach } \\
\text { Alpha }\end{array}$ & $\begin{array}{l}\text { Nilai } \\
\text { Standarisasi }\end{array}$ & Keterangan \\
\hline 1 & Pengembangan Karir $\left(\mathrm{X}_{1}\right)$ & 0,886 & 0,60 & Reliabel \\
\hline 2. & Penempatan Kerja $\left(\mathrm{X}_{2}\right)$ & 0,878 & 0,60 & Reliabel \\
\hline 3. & Tingkat Pendidikan $\left(\mathrm{X}_{3}\right)$ & 0,708 & 0,60 & Reliabel \\
\hline 4. & Tekhnologi Informasi $\left(\mathrm{X}_{4}\right)$ & 0,862 & 0,60 & Reliabel \\
\hline 5. & Fasilitas Kerja $\left(\mathrm{X}_{5}\right)$ & 0,865 & 0,60 & Reliabel \\
\hline 6. & Kinerja Karyawan $(\mathrm{Y})$ & 0,919 & 0,60 & Reliabel \\
\hline
\end{tabular}

Sumber : Data Primer yang diolah,2018

Berdasarkan tabel 8 diatas dapat disimulkan sama variabel penelitian memiliki nilai Cronbach Alpha di atas 0,60. Maka dapat disimpulkan bahwa semua variabel dalam penelitian ini memenuhi kriteria reliabilitas.

\section{Uji Asumsi Klasik}

\section{Uji Multikolinieritas}

Pengujian multikolinieritas bertujauan untuk mengetahui hubungan yang sempurna dengan antarvariabel bebas dalam model regresi. Gejala Multikolineritas dapat dilihat dari nilai tolerance dan nilai Varian Inflation Factor (VIF). Bila nilai VIF lebih kecil dari 10 dan nilai toleransinya diatas 0,1 atau $10 \%$ maka dapat disimpulkan bahwa model regresi tersebut tidak terjadi multikolineritas (Ghozali,2006).

\section{Tabel 9}

\section{Uji Multikolinieritas}

\begin{tabular}{|l|l|l|l|}
\hline No & Variabel & Nilai Tolerance & Nilai VIF (\%) \\
\hline 1 & Pengembangan karir $\left(\mathrm{X}_{1}\right)$ & 0.784 & 1.275 \\
\hline 2. & Penempatan Kerja $\left(\mathrm{X}_{2}\right)$ & 0.677 & 1.477 \\
\hline 3. & Tingkat Pendidikan $\left(\mathrm{X}_{3}\right)$ & 0.780 & 1.281 \\
\hline 4. & Tekhnologi Informasi $\left(\mathrm{X}_{4}\right)$ & 0.542 & 1.846 \\
\hline 5. & Fasilitas Kerja $\left(\mathrm{X}_{5}\right)$ & 0.554 & 1.807 \\
\hline
\end{tabular}

Data Primer yang diolah, 2018

Berdasarkan hasil uji multikolineritas diatas menunjukan bahwa nilai VIF semua variabel bebas lebih dari 10\% yang berarti tidak terjadi kolerasi antar variabel bebas. Dengan demikian dapat disimpulkan bahwa tidak terdapat gejala multikolineritas antar variabel bebas dengan model regresi. 


\section{Uji Heterokedastisitas}

Uji ini bertujuan untuk menguji apakah dalam sebuah model regresi terjadi ketidaksamaan varians dari residual, dari satu pengamatan ke pengamatan yang lain. Jika varians dari residual dari satu pengamatan ke pengamatan yang lain tetap, maka disebbut homoskedasitas dan jika varians berbeda disebut heterokedastisitas. Model regresi yang baik adalah tidak terjadi heterokedastisitas. Untuk mendeteksi ada tidaknya heterokedastisitas dapat digunakan metode grafik Scatteplot yang dihasilkan dari output program SPSS versi 23. Apabila pada gambar menunjukkan pada titik-titik menyebar secara acak tersebar baik di atas maupun dibawah angka 0 (nol) pada sumbu Y, maka hal ini dapat disimpulkan tidak terjadi adanya heterokedastisitas pada model regresi (Ghozali,2005).

Dari gambar grafik dibawah ini terlihat titik-titik yang menyebar secara acak, serta tersebar baik di atas maupun dibawah angka 0 (nol) pada sumbu Y, hal ini berarti

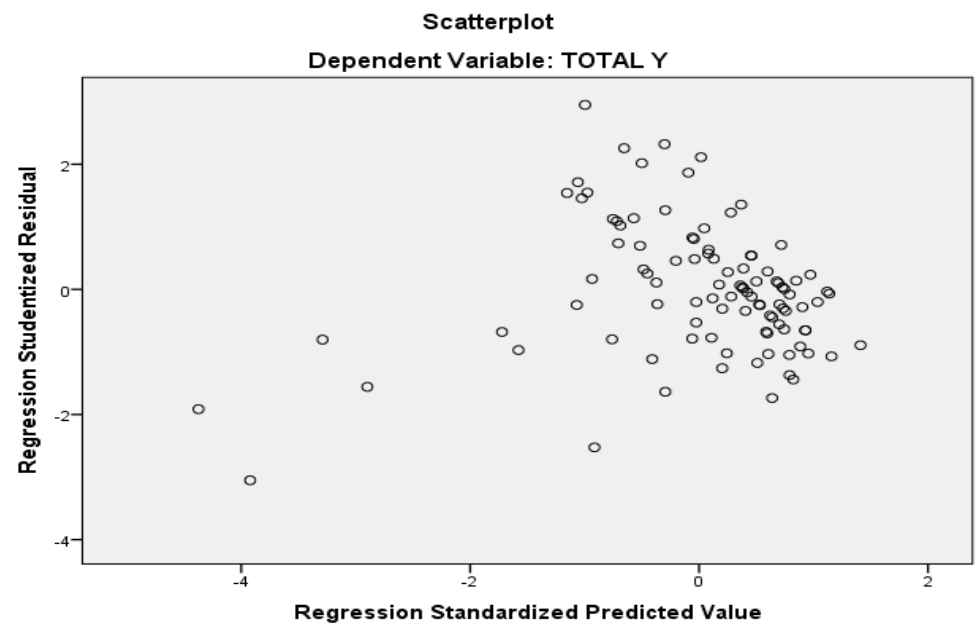

tidak terjadi penyimpangan asumsi klasik heterokedastisitas pada model regresi yang dibuat, dengan kata lain menerima hipotesis homoskedastisitas.

Sumber: Output SPSS 23,2018

\section{Gambar 2}

\section{Hasil Output SPSS 23 : Pengujian Heterokedastisitas}

\section{Uji Normalitas}

Uji Normalitas bertujuan untuk menguji apakah dalam model regresi, variabel bebas dan variabel terikat, keduanya terdistribusikan secara normal ataukah tidak. Normalitas data dalam penelitian dilihat dengan cara memperhatikan titik-titik pada 
Normal P-Plot of Regression Standardized Residual dari variabel terikat. Persyaratan dari uji normalitas adalah jika data meyebar di sekitas garis diagonal dan mengikuti arah garis diagonal maka model regresi memenuhi asumsi normalitas. Jika data menyebar jauh dari garis diagonaldan tidak mengikuti garis diagonal, maka model regresi tidak memenuhi asumsi normalitas.

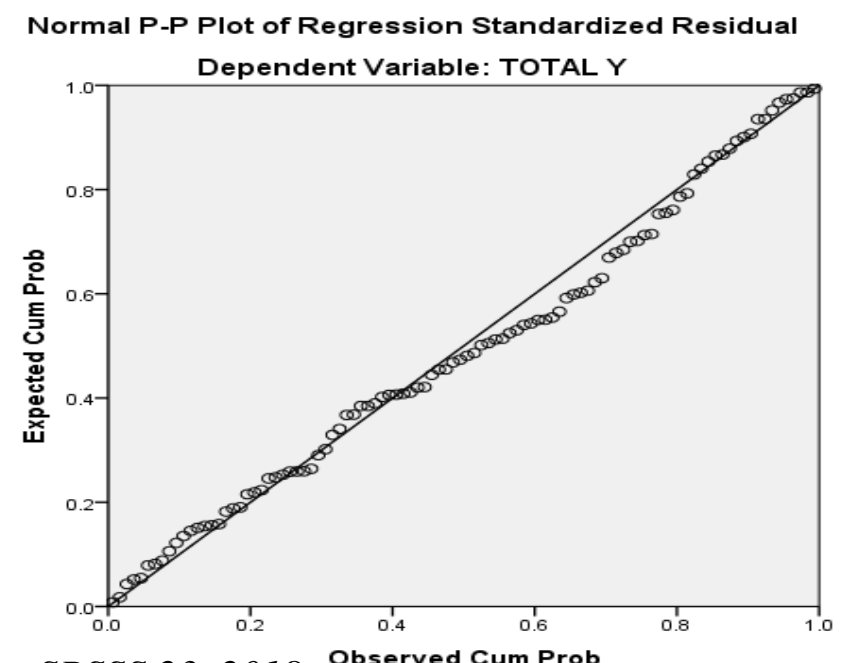

Sumber : Output SPSSS 23, 2018

Gambar 3

Hasil Output SPSS 23 : Grafik Pengujian Nornalitas

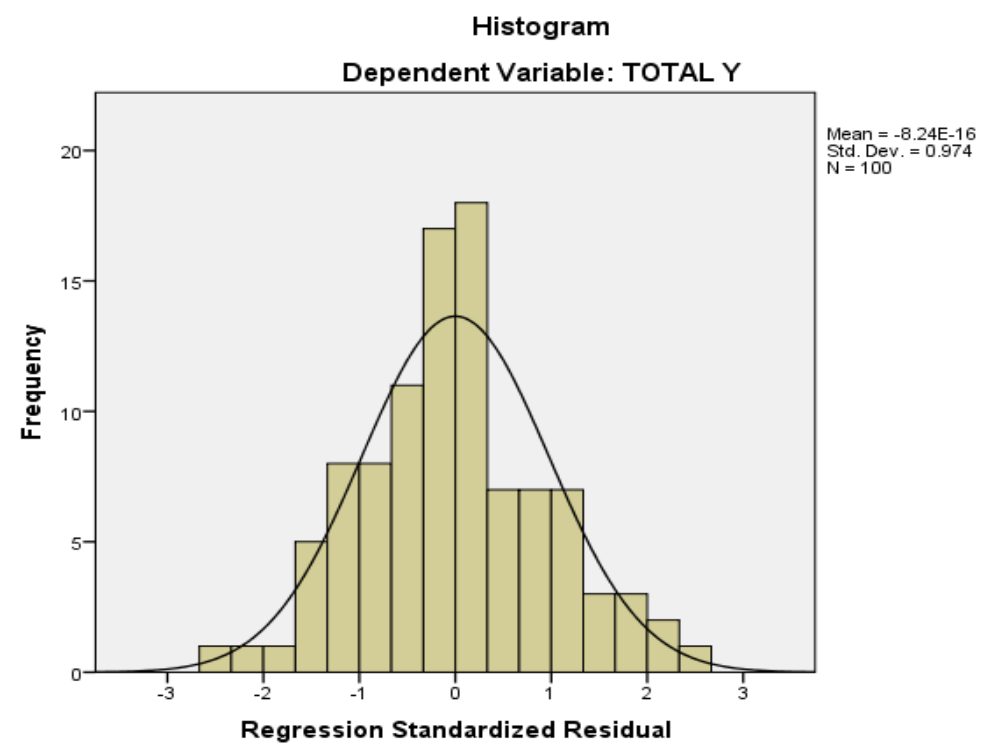

Sumber: Output SPSS 23, 2018

\section{Gambar 4}

Output SPSS 23 : Histogram Pengujian Normalitas 
Dapat disimpulkan bahwa pada grafik normal probability plot terlihat titik-titik menyebar disekitar garis diagonal dan penyebarannya mengikuti arah garis diagonal, begitu pula dengan grafik histogram yang memberikan pola distribusi yang normal (tidak terjadi kemirigan). Kedua grafik diatas menunjukkan bahwa model regresi layak pakai karena memenuhi asumsi normalitas. Kelemahan uji normalitas dengan menggukan Normal Probality Plot adalah biasanya penilaian yang bisa mengandung unsure penilaian secara subjektif. Maka penulis juga menyajiakan data uji normalitas dengan Kolmogrov-Smirnov. Berikut adalah table uji normalitas dengan KolmogrovSmirnov :

Tabel 10

Hasil Uji Normalitas dengan Kolmogrov-Smirnov

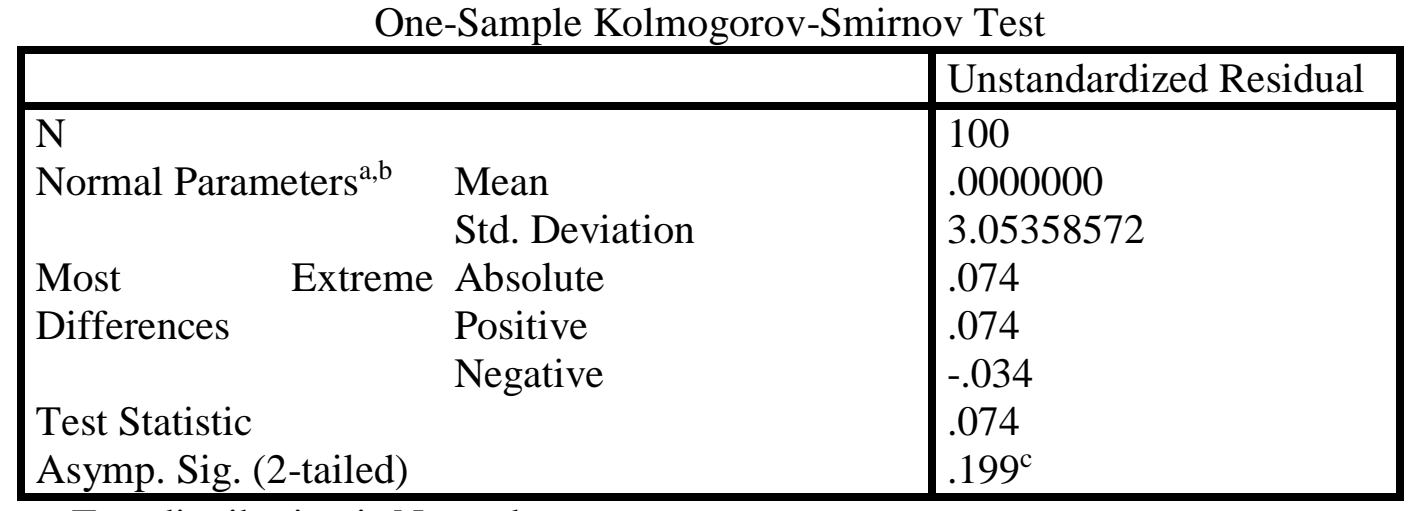

a. Test distribution is Normal.

b. Calculated from data.

Sumber: Output SPSS 23, 2018

Pada table 10 diatas dapat dilihat nilai sig (2-tailed) menunjukkan angka 0,199. Angka tersebut lebih besar dari alpha dalam penelitian ini yaitu 0,050 (5\%). Maka dari itu dapat disimpulkan model regresi berganda dalam penelitian ini telah terbukti memenuhi asumsi normalitas dan data terdistribusi normal.

\section{Uji Autokorelasi}

Uji autokorelasi digunakan untuk mengetahui ada atau tidaknya penyimpangan asumsi klasik autokorelasi yaitu korelasi yang terjadi antara residual pada sutu pengamatan daengan pengamatan lain pada model regresi. Persyaratan yang harus terpenuhi adalah titik adanya autokorelasi dan model regresi. 
Tabel 11

Model Summary ${ }^{\mathrm{b}}$

\section{Tabel Durbin Waston (DW) $5 \%$}

\begin{tabular}{|l|l|l|l|l|l|}
\hline Model & $\mathrm{R}$ & R Square & $\begin{array}{l}\text { Adjusted R } \\
\text { Square }\end{array}$ & $\begin{array}{l}\text { Std. Error of } \\
\text { the Estimate }\end{array}$ & Durbin-Watson \\
\hline 1 & $.880^{\mathrm{a}}$ & .774 & .762 & 3.1337 & 2.199 \\
\hline
\end{tabular}

a. Predictors: (Constant), pengembangan karir, penempatan kerja, tingkat pendidikan, teknologi informasi, fasilitas kerja,

b. Dependent Variable: Kinerja Karyawan

Sumber: Output SPSS 23, 2018

Berdasarkan hasil output SPSS 23 tentang uji autokorelasi dengan Durbin Watson, diketahui dengan nilai 2.199, selanjutnya nilai dibandingkan dengan nilai table signifikan 5\%, jumlah sampel $\mathrm{N}=100$ dan jumlah variabel independen $5(\mathrm{~K}=5)$ yang menghasilkan nilai dl sebesar 1,5710, sehingga diperoleh du 1,7804. Nilai DW sebesar 2,199 lebih besar dari batas atas du yakni 1,7804 dan kurang $(5-1,7804=3,2196)$. Sehingga dapat disimpulkan bahwa tidak terdapat autokorelasi.

\section{Analisis Persamaan Regresi Linier Berganda}

Model persamaan regresi yang baik adalah yang memenuhi persyaratan asumsi klasik, antara lain semua data berdistribusi normal, model harus bebas dari gejala multikolinieritas dan terbebas dari heteroskedasitas. Dari analisis sebelumnya telah terbukti bahwa model persamaan yang diajukan dalam penelitian ini telah memenuhi persyaratan asumsi klasik, sehingga model persamaan dalam penelitian ini sangat dianggap baik. Analisis regresi digunakan untuk menguji hipotesis tentang pengaruh secara parsial variabel bebas terhadap variabel terikat. Berdasarkan estimasti berganda dengan program SPSS 23 diperoleh hasil seperti pada table 12

Tabel 12

Hasil Regresi

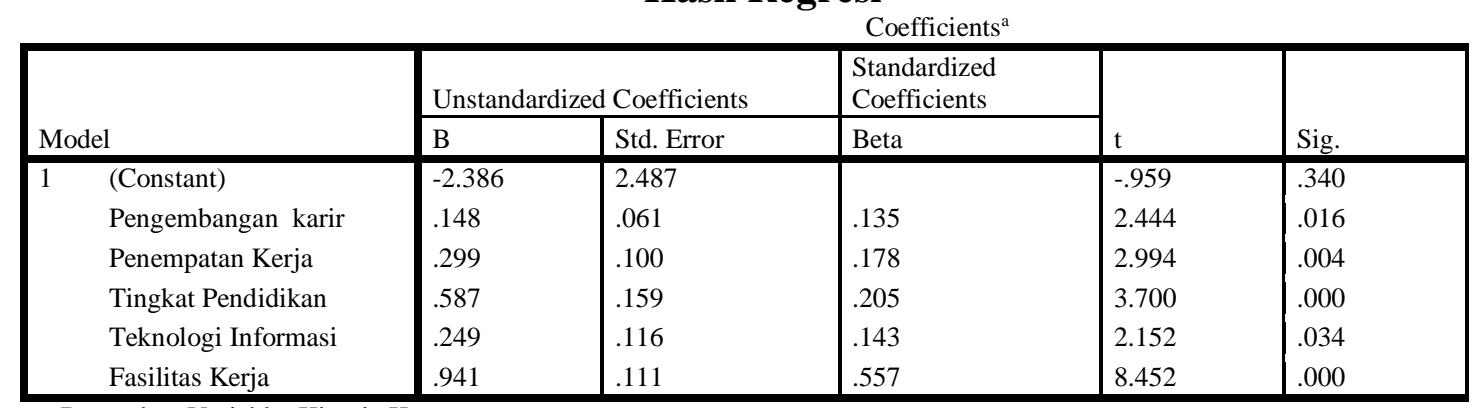

a. Dependent Variable: Kinerja Karyawan

Sumber: Output SPSS 23, 2018 
Berdasarkan tabel 2. Diatas dapat diketahui persamaan regreesi yang terbentuk adalah:

$$
Y=-2,386+0,148 X_{1}+0,299 X_{2}+0,587 X_{3}+0,249 X_{4}+0,941 X_{5}
$$

Keterangan :

Y : Kinerja Karyawan

$\mathrm{X}_{1}$ : Pengembangan Karir

$\mathrm{X}_{2}$ : Penempatan Kerja

$\mathrm{X}_{3}$ : Tingkat Pendidikan

$\mathrm{X}_{4}$ : Teknologi Informasi

$\mathrm{X}_{5}$ : Fasilitas Kerja

Dari persamaan regresi linier berganda tersebut diatas menunjukkan bahwa :

1. Nilai konstanta sebesar -2,386 mempunyai arti jika tidak ada pengaruh variabel pengembangan karir X1), penempatan kerja (X2), tingkat pendidikan (X3), teknologi informasi (X4), fasilitas kerja (X5), maka kinerja pegawai turun -2,386.

2. $\beta 1$ ( nilai koefisien regresi X1) 0,148 sebesar mempunyai arti koefisien regresi pengembangan karir (X1) bernilai positif yang berarti bahwa setiap tambahan 1(satu) variabel pengembangan karir maka akan meningkatkan kinerja karyawan akan meningkatkan kinerja karyawan sebesar 0,148 atau sebesar 14,8 \%.

3. $\beta 2$ ( nilai koefisien regresi X2) sebesar 0,299 mempunyai arti koefisien regresi penempatan kerja (X2) bernilai positif yang berarti bahwa setiap tambahan 1 (satu) variabel penempatan kerja maka akan meningkatkan kinerja karyawan sebesar 0,299 atau $29,9 \%$.

4. B3 ( nilai koefisien regresi X3) sebesar 0,587 mempunyai arti koefisien regresi tingkat pendidikan (X3) bernilai positif yang berarti bahwa setiap tambahan 1(satu) variabel tingkat pendidikan maka akan meningkatkan kinerja karyawan sebesar 0,587 atau $58,7 \%$.

5. $\beta 4$ ( nilai koefisien regresi $\mathrm{X} 4$ ) sebesar 0,249 mempunyai arti koefisien regresi teknologi informasi (X4) bernilai positif yang berarti bahwa setiap tambahan 1(satu) variabel teknologi informasi maka akan meningkatkan kinerja karyawan sebesar 0,249 atau $24,9 \%$. 
6. $\beta 5$ ( nilai koefisien regresi X5) sebesar 0,941 mempunyai arti koefisien regresi fasilitas kerja (X5) bernilai positif yang berarti bahwa setiap tambahan 1(satu) variabel fasilitas kerja maka akan meningkatkan kinerja karyawan sebesar 0,941 atau $94,1 \%$

7. Berdasarkan nilai persamaan regresi yang ditunjukkan dengan nilai koefisien regresi, maka dapat disimpulkan bahwa variabel yang dominan dalam mempengaruhi kinerja pegawai adalah faktor fasilitas kerja. Hal ini dapat dilihat dari koefisien regresinya yang paling tinggi yaitu 0,941 atau $94,1 \%$.

\section{Uji Hipotesis}

\section{Uji t (Uji t)}

Uji regresin secara parsial atau uji yang digunakan untuk mengetahui ada atau tidaknya pengaruh yang signifikan antar masing-masing variabel bebas dengan variabel terikat. Pada penelitian ini penulis menetapkan tingkat signifikansi sebesar 5\% atau 0,05. Jika tingakat signifikansi suatu variabel bebas $<0,05$ maka Ho ditolak dan Ha diterima. Begitu juga sebaliknya apabila tingkat signifikansi atau variabel bebas $>0,05$, maka Ho diterima dan Ha ditolak. Hasil statistic uji t dalam penelitian ini dapat dilihat dari tabel 13 berikut ini :

\section{Tabel 13}

Hasil Uji t Secara Parsial

Coefficients $^{\mathrm{a}}$

\begin{tabular}{|c|c|c|c|c|c|c|c|}
\hline \multirow[b]{2}{*}{ Model } & \multicolumn{2}{|c|}{$\begin{array}{l}\text { Unstandardi } \\
\text { zed } \\
\text { Coefficients }\end{array}$} & \multirow{2}{*}{\begin{tabular}{|l}
$\begin{array}{l}\text { Standardize } \\
\mathrm{d}\end{array}$ \\
Coefficients \\
Beta
\end{tabular}} & \multirow[b]{2}{*}{$t$} & \multirow[b]{2}{*}{ Sig. } & \multicolumn{2}{|c|}{$\begin{array}{l}\text { Collinearity } \\
\text { Statistics }\end{array}$} \\
\hline & B & $\begin{array}{l}\text { Std. } \\
\text { Error }\end{array}$ & & & & $\begin{array}{l}\text { Toleranc } \\
\mathrm{e}^{-}\end{array}$ & VIF \\
\hline 1 (Constant) & $-\overline{2.386}$ & 2.487 & & -.959 & .340 & & \\
\hline $\begin{array}{l}\text { Pengembangan } \\
\text { Karir }\end{array}$ & .148 & .061 & .135 & 2.444 & .016 & .784 & 1.275 \\
\hline Penempatan Kerja & .299 & .100 & .178 & 2.994 & .004 & .677 & 1.477 \\
\hline $\begin{array}{l}\text { Tingkat } \\
\text { Pendidikan }\end{array}$ & .587 & .159 & .205 & 3.700 & .000 & .780 & 1.281 \\
\hline $\begin{array}{l}\text { Teknologi } \\
\text { Informasi }\end{array}$ & .249 & .116 & .143 & 2.152 & .034 & .542 & 1.846 \\
\hline Fasilitas Kerja & .941 & .111 & .557 & 8.452 & .000 & .554 & 1.807 \\
\hline
\end{tabular}

a. Dependent Variable: Kinerja Karyawan

Sumber: Output SPSS 23, 2018 
Hipotesis :

\section{Uji Hipotesis $1\left(\mathbf{H}_{1}\right)$}

Berdasarkan hasil uji t-test tabel 5. dapat dilihat bahwa nilai t untuk variabel pengembangan karir (X1) terhadap kinerja karyawan (Y) sebersar 2.444 dan hasil Coefficient dengan probabilitas signifikan 0,016 lebih dari kecil dari alpha 0,05, maka Ho ditolak dan Ha diterima. Hal ini berarti analisis dan pengujian hipotesis penelitian ini diketahui bahwa terdapat pengaruh positif dan signifikan pengembangan karir (X1), terhadap kinerja karyawan (Y), dengan kata lain hipotesis pertama terbukti.

\section{Uji Hipotesis $2\left(\mathrm{H}_{2}\right)$}

Berdasarkan hasil uji t-test tabel 5. dapat dilihat bahwa nilai t untuk variabel penempatan kerja $\left(\mathrm{X}_{2}\right)$ terhadap kinerja karyawan $(\mathrm{Y})$ sebersar 2,994 dan hasil Coefficient dengan probabilitas signifikan 0,004 lebih dari kecil dari alpha 0,05, maka Ho ditolak dan Ha diterima. Hal ini berarti analisis dan pengujian hipotesis penelitian ini diketahui bahwa terdapat pengaruh positif dan signifikan penempatan kerja $\left(\mathrm{X}_{2}\right)$, terhadap kinerja karyawan $(\mathrm{Y})$, dengan kata lain hipotesis kedua terbukti.

\section{Uji Hipotesis $3\left(\mathrm{H}_{3}\right)$}

Berdasarkan hasil uji t-test tabel 5. dapat dilihat bahwa nilai t untuk variabel tingkat pendidikan $\left(\mathrm{X}_{3}\right)$ terhadap kinerja karyawan $(\mathrm{Y})$ sebersar 3,700 dan hasil Coefficient dengan probabilitas signifikan 0,000 lebih dari kecil dari alpha 0,05, maka Ho ditolak dan Ha diterima. Hal ini berarti analisis dan pengujian hipotesis penelitian ini diketahui bahwa terdapat pengaruh positif dan signifikan tingkat pendidikan $\left(\mathrm{X}_{3}\right)$, terhadap kinerja karyawan $(\mathrm{Y})$, dengan kata lain hipotesis ketiga terbukti.

\section{Uji Hipotesis $4\left(\mathrm{H}_{4}\right)$}

Berdasarkan hasil uji t-test tabel 5. dapat dilihat bahwa nilai t untuk variabel teknologi informasi $\left(\mathrm{X}_{4}\right)$ terhadap kinerja karyawan $(\mathrm{Y})$ sebersar 2,152 dan hasil Coefficient dengan probabilitas signifikan 0,034 lebih dari kecil dari alpha 0,05, maka Ho ditolak dan Ha diterima. Hal ini berarti analisis dan pengujian hipotesis penelitian ini diketahui bahwa terdapat pengaruh positif dan signifikan teknologi 
informasi $\left(\mathrm{X}_{4}\right)$, terhadap kinerja karyawan $(\mathrm{Y})$, dengan kata lain hipotesis keempat terbukti.

\section{Uji Hipotesis 5 (H5)}

Berdasarkan hasil uji t-test tabel 5. dapat dilihat bahwa nilai t untuk variabel fasilitas kerja $\left(\mathrm{X}_{5}\right)$ terhadap kinerja karyawan (Y) sebersar 8,452 dan hasil Coefficient dengan probabilitas signifikan 0,000 lebih dari kecil dari alpha 0,05, maka Ho ditolak dan Ha diterima. Hal ini berarti analisis dan pengujian hipotesis penelitian ini diketahui bahwa terdapat pengaruh positif dan signifikan fasilitas kerja $\left(\mathrm{X}_{5}\right)$, terhadap kinerja karyawan $(\mathrm{Y})$, dengan kata lain hipotesis kelima terbukti.

\section{Uji F (Pengujian hipotesis secara simultan)}

Uji $\mathrm{F}$ digunakan untuk melihat ada atau tidaknya pengaruh signifikan secara simultan antara semua variabel bebas dengan variabel terikat. Jika tingkat signifikansi berada pada angka $<0,050$, maka Ho ditolak dan Ha diterima. Dan sebaliknya jika tingkat signifikansi berada pada angka > 0,050 maka Ho diterima dan Ha ditolak. Hasil uji regresi secara simultan adalah sebagai berikut :

Tabel 14

Hasil Analisis Regresi Secara Simultan ANOVA $^{\mathrm{a}}$

\begin{tabular}{|ll|l|l|l|l|l|}
\hline \multicolumn{2}{|l|}{ Model } & $\begin{array}{l}\text { Sum } \\
\text { Squares }\end{array}$ & Df & $\begin{array}{l}\text { Mean } \\
\text { Square }\end{array}$ & F & Sig. \\
\hline 1 & Regression & 3168.596 & 5 & 633.719 & 64.531 & $.000^{\mathrm{b}}$ \\
& Residual & 923.114 & 94 & 9.820 & & \\
& Total & 4091.710 & 99 & & & \\
\hline
\end{tabular}

a. Dependent Variable: Kinerja Karyawan

b. Predictors: (Constant), fasilitas kerja, tingkat pendidikan, pengembangan karir , penempatan kerja, teknologi informasi.

Sumber: Output SPSS 23, 2018

\section{Uji Koefisien Determinasi $\left(\mathbf{R}^{\mathbf{2}}\right)$}

Koefisien determinasi $\left(\mathrm{R}^{2}\right)$ pada intinya mengukur seberapa jauh kemampuan model dalam menerangkan variasi variabel dependen. Nilai koefisien determinasi adalah antara nol sampai satu $\left(0<\mathrm{R}^{2}<1\right)$. Nilai $\mathrm{R}^{2}$ yang kecil berarti kemampuan variabel-variabel independen dalam menjelaskan variasi variabel dependen sangat 
terbatas. Berikut ini adalah besarnya pengaruh variabel independen terhadap variabel dependent dapat dilihat pada tebel sebagai berikut:

Tabel 15

Hasil Uji Koefisien Determinasi $\left(\mathbf{R}^{2}\right)$

Model Summary ${ }^{b}$

\begin{tabular}{|l|l|l|l|l|}
\hline Model & $\mathrm{R}$ & R Square & Adjusted R Square & $\begin{array}{l}\text { Std. Error of the } \\
\text { Estimate }\end{array}$ \\
\hline 1 & $.880^{\mathrm{a}}$ & .774 & .762 & 3.1337 \\
\hline
\end{tabular}

a. Predictors: (Constant), Fasilitas kerja, tingkat pendidikan, pengembangan karir , penempatan kerja, teknologi informasi.

b. Dependent Variable: Kinerja Karyawan

Sumber: Output SPSS 23, 2018

Hasil table 15 diatas menunjukkan nilai Adjusted $R$ Square adalah sebesar 0,762. Maka dapat dijelaskan bahwa variabel terikat yaitu kinerja karyawan dapat dijelaskan oleh variabel bebas yaitu pengembangan karir, penempatan kerja, tingkat pendidikan, teknologi informasi dan fasilitas kerja sebesar $76,2 \%$. Sedangkan $23,8 \%$ lainnya dijelaskan oleh variabel lain yang tidak termasuk dalam penelitian ini yaitu disiplin kerja, kepuasan kerja, lingkungan kerja, motivasi kerja, kompensasi dan lainlain.

\section{Pembahasan}

\section{Pengaruh Pengembangan Karir terhadap Kinerja Karyawan}

Berdasarkan hasil penelitian secara parsial (Uji t), diketahui bahwa nilai $\mathrm{t}$ untuk variabel pengembangan karir $\left(\mathrm{X}_{1}\right)$ terhadap kinerja karyawan $(\mathrm{Y})$ sebesar 2,444, mempunyai pengaruh positif yang artinya bahwa semakin tinggi pengembangan karir seorang karyawan dalam perusahaan, maka akan meningkatkan kinerja karyawan. Sebaliknya, jika semakin rendah pengembangan karir seorang karyawan pada suatu perusahaan, maka akan menurun kinerja karyawan pada perusahaan tersebut.

Dari hasilnya Coefficient menunjukkan probabilitas signifikansi 0,016, nilai tersebut lebih kecil darinilai alpha 0,050, maka $\mathrm{Ho}_{1}$ ditolak dan $\mathrm{Ha}_{1}$ diterima. Hal ini berarti bahwa hasil analisis pengujian hipotesis penelitian ini, diketahui bahwa ada pengaruh yang signifikan antar variabel pengembangan karir $\left(\mathrm{X}_{1}\right)$ terhadap kinerja karyawan $(\mathrm{Y})$. Hasil ini mendukung hasil penelitian 
dari Siregar (2010), Arifin (2014), Verlita Yolandari (2011), yang memperoleh hasil bahwa pengembangan karir berpengaruh positif dan signifikan terhadap kinerja karyawan.

Menurut I Komang A. dkk (2012) pengembangan karir adalah peningkatan pribadi yang dilakukan seseorang untuk mencapai suatu rencana karir dan peningkatan oleh departemen personalia untuk mencapai suatu rencana kerja sesuai dengan jalur atau jenjang organisasi. Jadi betapa pun baiknya suatu rencana karir yang telah dibuat oleh seorang pekerja disertai oleh suatu tujuan karir yang wajar dan realistik, rencana tersebut tidak akan menjadi kenyataan tanpa adanya pengembangan karir yang sistematik dan programatik. Karena perencanaan karir adalah keputusan yang diambil sekarang tentang hal-hal yang akan dikerjakan pada masa depan, berarti bahwa seseorang yang sudah menetapkan rencana karirnya, perlu mengambil langkah-langkah tertentu untuk mewujudkan rencana tersebut.

\section{Pengaruh Penempatan Kerja terhadap Kinerja Karyawan}

Berdasarkan hasil penelitian secara parsial (Uji t), diketahui bahwa nilai t untuk variabel penempatan kerja $\left(\mathrm{X}_{2}\right)$ terhadap kinerja karyawan $(\mathrm{Y})$ sebesar 2,944 mempunyai pengaruh positif yang artinya bahwa semakin tinggi penempatan kerja seorang karyawan dalam perusahaan, maka akan meningkatkan kinerja karyawan. Sebaliknya, jika semakin rendah penempatan kerja seorang karyawan pada suatu perusahaan,maka akan menurun kinerja karyawan pada perusahaan tersebut.

Dari hasilnya Coefficient menunjukkan probabilitas signifikansi 0,004, nilai tersebut lebih kecil darinilai alpha 0,050, maka Ho ditolak dan $\mathrm{Ha}_{2}$ diterima. Hal ini berarti bahwa hasil analisis pengujian hipotesis penelitian ini, diketahui bahwa ada pengaruh yang signifikan antar variabel penempatan kerja $\left(\mathrm{X}_{2}\right)$ terhadap kinerja karyawan $(\mathrm{Y})$. Hasil ini mendukung hasil penelitian dari Hasibuan, Melayu S.P (2000), Veithzal Rifai, (2005), Hasibuan (2009), Rivai dan Sagala (2009) yang memperoleh hasil bahwa penempatan kerja berpengaruh positif dan signifikan terhadap kinerja karyawan.

Mangkuprawira (2002) Penempatan merupakan proses pemberian tugas dan pekerjaan kepada tenaga kerja yang lulus seleksi untuk dilaksanakan sesuai 
ruang lingkup yang telah ditetapkan, serta mampu mempertanggungjawabkan segala resiko dan kemungkinan yang terjadi atas tugas dan pekerjaan, wewenang, serta tanggung jawab. Sehingga dengan kata lain penempatan kerja memberikan pengaruh terhadap tercapainya atau tidaknya tujuan perusahaan yang terlihat pada kinerja karyawan. Dengan penempatan kerja yang tepat seorang karyawan dapat mengerjakan tugasnya dengan maksimal serta dapat terus memberikan keahlian pada karyawan tersebut.

\section{Pengaruh Tingkat Pendidikan terhadap Kinerja Karyawan}

Berdasarkan hasil penelitian secara parsial (Uji t), diketahui bahwa nilai $\mathrm{t}$ untuk variabel penempatan kerja $\left(\mathrm{X}_{2}\right)$ terhadap kinerja karyawan $(\mathrm{Y})$ sebesar 3,700 , mempunyai pengaruh positif yang artinya bahwa semakin tinggi tingakat pendidikan seorang karyawan dalam perusahaan, maka akan meningkatkan kinerja karyawan. Sebaliknya, jika semakin rendah tingakat pendidikan seorang karyawan pada suatu perusahaan,maka akan menurun kinerja karyawan pada perusahaan tersebut.

Dari hasilnya Coefficient menunjukkan probabilitas signifikansi 0,000, nilai tersebut lebih kecil darinilai alpha 0,050, maka $\mathrm{Ho}_{3}$ ditolak dan $\mathrm{Ha}_{3}$ diterima. Hal ini berarti bahwa hasil analisis pengujian hipotesis penelitian ini, diketahui bahwa ada pengaruh yang signifikan antar variabel tingakat pendidikan $\left(\mathrm{X}_{3}\right)$ terhadap kinerja karyawan $(\mathrm{Y})$. Hasil inimendukung hasil penelitian S.P Siagian (1986), Ki Hajar Dewantara, Ahmad D.Marimba, Martinus Jan Langeveld, Horne, Stella Van Petten Henderson, Gunning dan Kohnstam,Cater V. Good dan juga Undang-Undang No. 20 tahun 2003. Yang memperoleh hasil bahwa tingkat pendidikan berpengaruh positif dan signifikan terhadap kinerja karyawan.

Sesuai dengan teori yang dikemukakan oleh horne bahwa pendidikan adalah alat dimana kelompok sosial melanjutkan keberadaannya dalam mempengaruhi diri sendiri serta menjada idealismenya. Pada sebuah instansi atau perusahaancara kerja karyawan akan sangat mempengaruhi hasil dari pekerjaan. Tingkat Pendidikan yang dimiliki seseorang mempengaruhi cara kerja dan hasil dari pekerjaan tersebut. Semakin tinggi Tingkat Pendidikan 
seseorang maka semakin banyak keahlian dan pengetahuan yang dimilikiseseorang yang nantinya akan mendukung kinerja perusahaan. Pendidikan dan pelatihan merupakan salah satu bentuk pembinaan terhadap pegawai negri sipil untuk menambah pengetahuan dan ketrampilan sehingga dapat mengikuti perkembangan, perubahan sistem dam teknologi dan menjalankan tugas yang dibebankan kepada karyawan.

\section{Pengaruh Teknologi Informasi terhadap Kinerja Karyawan}

Berdasarkan hasil penelitian secara parsial (Uji t), diketahui bahwa nilai t untuk variabel teknologi informasi $\left(\mathrm{X}_{4}\right)$ terhadap kinerja karyawan (Y) sebesar 2,152 , mempunyai pengaruh positif yang artinya bahwa semakin tinggi tingakat pendidikan seorang karyawan dalam perusahaan, maka akan meningkatkan kinerja karyawan. Sebaliknya, jika semakin rendah teknologi informasi seorang karyawan pada suatu perusahaan,maka akan menurun kinerja karyawan pada perusahaan tersebut.

Dari hasilnya Coefficient menunjukkan probabilitas signifikansi 0,034, nilai tersebut lebih kecil darinilai alpha 0,050, maka Ho ditolak dan $\mathrm{Ha}_{2}$ diterima. Hal ini berarti bahwa hasil analisis pengujian hipotesis penelitian ini, diketahui bahwa ada pengaruh yang signifikan antar variabel teknologi informasi $\left(\mathrm{X}_{4}\right)$ terhadap kinerja karyawan $(\mathrm{Y})$. Hal ini mendukung hasil penelitian dari Haag dan Keen (1996) Martin (1999), William dan Sawyer (2003) yang memperoleh hasil bahwa tekonologi informasi berpengaruh positif dan signifikan terhadap kinerja karyawan.

Teknologi Informasi adalah seperangkat alat yang membantu karyawam bekerja dengan informasi dan melaksanakan tugas-tugas yang berhubungan dengan kata lain teknologi informasi (Haag dan Keen, 1996). Sehingga dengan kata lain teknologi informasi memberikan pengaruh terhadap tercaoainya atau tidaknya tujuan perusahaan yang terlihat pada kinerja karyawan. Dengan adanya teknologi informasi akan mempermudah segala pekerjaan dan akan lebih menghemat waktu.

\section{Pengaruh Fasilitas Kerja terhadap Kinerja Karyawan}

Berdasarkan hasil penelitian secara parsial (Uji t), diketahui bahwa nilai t untuk variabel teknologi informasi $\left(\mathrm{X}_{5}\right)$ terhadap kinerja karyawan $(\mathrm{Y})$ sebesar 
8,452, mempunyai pengaruh positif yang artinya bahwa semakin lengkap fasilitas kerja dalam sebuah perusahaan maka seorang karyawan akan meningkatkan kinerja karyawan. Sebaliknya, jika semakin kurang lengkap fasilitas kerja dalam sebuah perusahaan maka seorang karyawan akan menurun kinerja karyawan pada perusahaan tersebut.

Dari hasilnya Coefficient menunjukkan probabilitas signifikansi X , nilai tersebut lebih kecil darinilai alpha 0,050, maka $\mathrm{Ho}_{5}$ ditolak dan $\mathrm{Ha}_{5}$ diterima. Hal ini berarti bahwa hasil analisis pengujian hipotesis penelitian ini, diketahui bahwa ada pengaruh yang signifikan antar variabel fasilitas kerja $\left(\mathrm{X}_{5}\right)$ terhadap kinerja karyawan (Y). Hal ini mendukung hasil penelitian Welli Fitra Hayati (2014), Nitisemito (2001), (Suhardi 2001). Bary, (2002). yang memperoleh hasil bahwa fasilitas kerja berpengaruh positif dan signifikan terhadap kinerja karyawan. Menurut Bary, (2002:67) menyatakan fasilitas kerja adalah sebagai sarana yang diberikan perusahaan untuk mendukung jalannya nada perusahaan dalam mencapai tujuan yang ditetapkan oleh pemegang kendali.

\section{DAFTAR PUSTAKA}

Aji Supriyanto. 2005. "Pengantar Teknologi Informasi". Jakarta: Edisi Pertama, penerbit Salemba Empat.

Angga Dewi, Ni Luh Putu Ariesta. 2016 : Pengaruh Pengembangan Karir Terhadap Kinerja Karyawan Melalui Mediasi Motivasi Kerja Pada Karya Mas Art Gallery. Bali: Fakultas Ekonomi dan Bisnis Universitas Udayana.

Awaluddin K, Syamsu Alam, Ria Mardiana Yusuf. 2015. Pengaruh Pemberian Fasilitas, Tingkat Pendidikan Dan Disiplin Kerja Terhadap Peningkatan Kinerja Pegawai Pada Badan Busat Statistik Kabupaten Maros. Universitas Hasanuddin.

G. Kelatow, Christian. 2016.Pengaruh Evaluasi Pekerjaan, Gaji Dan Fasilitas Kerja Terhadap Kinerja Pegawai Pada Rs. Pancaran Kasih Manado. Manado: Universitas Sam Ratulangi

Handoko, T. Hani, 2012. Manajemen Personalia dan Sumberdaya Manusia. Yogyakarta : Penerbit BPFE.

Hasibuan. 2006. Manajemen Sumber Daya Manusia. Edisi Revisi Penerbit Bumi Akasara. 
Husein, Umar. 2008. Metode Penelitian Untuk Kripsi dan Tesis Bisnis. Jakarta : PT. Raja Grafindo Persada.

Ikawinarti. 2011, Manajemen Personalia. Jakarta : Rineka Cipta.

Mangkunegara, Anwar Prabu. 2012. Manajemen Sumber Daya Perusahaan. Bandung: Remaja Rosdakarya.

Mangkunegara, Anwar Prabu. 2012. Manajemen Sumber Daya Perusahaan. Bandung: Remaja Rosdakarya.

Manullang, M, 2000. Manajemen Personalia. Penerbit Ghalia. Indonesia.

Ningrum Widhayu, dkk, 2013. Pengaruh Pendidikan dan Pelatihan Terhadap Kinerja Karyawan (Studi Pada Karyawan Joint Operating Body Pertamina-PertoChina East Java. Universitas Brawijaya. Malang: Jurnal Administrasi Bisnis (JAB). Vol.6 No.2 2013. http://administrasibisnis.studentjournal.ub .ac.id/index.php/jab/article/view/303. Di akses 17 Juni 2014. Hal. 1-8.

Nugroho,Novemy Triyandari. 2016. Pengaruh Penggunaan Teknologi Informasi Terhadap Kinerja Karyawan. Surakarta: STMIK Duta Bangsa.

Pedoman Skripsi , 2018 , Semarang: Universitas AKI.

Pojoh , Tirza Pingkan. 2014. Pengaruh Pendidikan Dan Pelatihan (Diklat) Terhadap Kinerja Karyawan Pada Pt Pln (Persero) Wilayah Suluttengo. Manado: Universitas Sam Ratulangi.

Rakhmansyah, Agil. 2014.Pengaruh Penggunaan Teknologi Informasi Terhadap Kinerja. Malang: Universitas Brawijaya.

Resiona, Fernandez. 2014. Pengaruh Penempatan, Lingkungan Kerja Fisik Dan Motivasi Kerja Terhadap Kinerja Pegawai Negeri Sipil Di Lingkungan BAPPEDA Kbupaten Flores Timur. Flores Timur: Indonesia Open University.

Rivai, Vethzal \& Basri. 2005. Performance Appraisal : Sistem yang tepat untuk Menilai Karyawan dan Meningkatkan Daya Saing Perusahaan. Jakarta : PT. Raja Grafindo. Persada.

Rivai, Vethzal, 2004. Manajemen Sumber Daya Manusia Untuk Perusahaan dari teori Ke Praktik. Jakarta : PT. Raja Grafindo. Persada.

Siagian, Sondang. 2007. Manajemen Sumber Daya Manusia. Jakarta: Bumi Aksara.

Simamora, Bilson. 2003. Penilaian Kinerja dalam Manajemen Perusahaan. Jakarta: Gramedia Pustaka. 
Sudarmanto. 2009. Kinerja dan pengembangan Kompetensi SDM. Teori, Dimensi Pengukuran dan Implementasi dalam Organisasi. Yogyakarta: Pustaka Pelajar.

Sugiyono, 2012. Statistika untuk Penilaian. Bandung: CV. Alfabeta.

Suliyanto, 2005. Ekonometrika Terapan - Teori dan Aplikasi dengan SPSS. Yogyakarta: ANDI.

Sutrisno, Edy. 2009. Manajemen Sumber Daya Manusia, Jakarta : Kencana Prenada Media Group.

Tirza Pingkan Pojoh, Bernhard Tewal2, dkk. 2014. Pengaruh Pendidikan Dan Pelatihan (Diklat) Terhadap Kinerja Karyawan Pada Pt Pln (Persero) Wilayah Suluttengo. Manado : Universitas Sam Ratulangi .

Wahab. 2012. Manajemen Sumber Daya Manusia. Jakarta : Erlangga.

Website: http//jateng.bkkbn.go.id

Yudiastira, Putu Pade, 2015. Pengaruh Teknologi Informasi, Disiplin Kerja, Intensif, Turnover, terhadap Kinerja Karyawan. Jakara: Universitas Pendidikan Indonesia. 
Majalah Ilmiah Solusi

Vol. 17, No. 4 Oktober 2019

ISSN : 1412-5331

Halaman ini sengaja dikosongkan 